\title{
Assessment of the Role of Laparoscopic Management in Patients with Complicated Appendicitis
}

\author{
Priyank Patel ${ }^{\circledR}$, Jaimini Jaiswal ${ }^{\odot 2}$ \\ ${ }^{1}$ Senior Resident, Department of Suregry, Dr N D Desai Faculty of Medical Sciences, Nadiad, Gujarat, India, ${ }^{2}$ Assistant Professor, Department of Surgery, Dr N D Desai \\ Faculty of Medical Sciences, Nadiad, Gujarat, India.
}

\section{Abstract}

Background: Present research aimed to evaluate the wellbeing and the effectiveness of laparoscopy for managing complicated appendicitis. Subjects and Methods: Present descriptive research was carry out on 50 patients at tertiary care institution of Gujarat for the period of 1 year. This study is including patients of complicated appendicitis undergoing laparoscopic management. Parameters studied included Age, Gender, WBC count, wound infection and hospital stay. Results: There was increase of total leucocytic count (leukocytosis) in most of the patients; Mean WBCs was 12.71 \pm 5.37. 33 patients had pus free IPF collection and perforated appendicitis (PA), 11 patients had turbid free IPF collection with AA (highly inflamed appendix), 2 case was mucocele of the appendix, 2 cases of appendicular abscess (3.3\%) and 2 cases of gangrenous appendix. Conclusion: management of complicated appendicitis laparoscopically is practicable, secure and can present a small occurrence of infectious impediments, fewer post-operative pain, fast revival and improved cosmesis on the cost of extended operating time than OA.

Keywords: Complicated Appendicitis, Hospital stay, Laparoscopy, Wound infection

Corresponding Author: Jaimini Jaiswal, Assistant Professor, Department of Surgery, Dr N D Desai Faculty of Medical Sciences, Nadiad, Gujarat, India.

E-mail: jaiminijaiswal12@yahoo.co.in

Received: 25 August 2020

Revised: 29 September 2020

Accepted: 08 October 2020

Published: 27 December 2020

\section{Introduction}

Appendicitis is the commonest abdominal surgical emergency in the world which may lead to complications like appendicular abscess or mass, gangrene, perforation and peritonitis. ${ }^{[1]}$ About seven percentage of the residents developed appendicitis in their existence, with crest occurrence amid the ages of 10 and 30 years, thus building appendectomy the mainly often executed abdominal operation. Complicated appendicitis has been linked with a important danger of postoperative septic difficulties, with wound infections and intraabdominal abscess formation. ${ }^{[2]}$ The possibility and strength of the laparoscopic approach has reason important argument mostly owing to premature information of the augmented occurrence of intra-abdominal abscess rateson the other hand, quite a few further fresh trials have establish a statistically significant lessening in premature postoperative complications with the laparoscopic approach to the end that it has really been future as the technique of option for complicated appendicitis. ${ }^{[3-12]}$

A great number of researches evaluates laparoscopic versus open appendectomy (OA) were carry out seeing as the primary details of laparoscopic appendectomy (LA) by Semm in 1983, [13-18] Consequently, complicated appendicitis is improved supervised by LA. ${ }^{[19]}$ Therefore, it is rational that LA could have compensation above OA in patients with complicated appendicitis, since LA is linked with fewer wound surface area out to contagion and possible assists straight apparition throughout peritoneal lavage. ${ }^{20]}$

Perforated appendicitis happens in $20 \%$ to $30 \%$ of acute appendicitis patients and is linked with greatly superior threats of postoperative infectious complications present study carry out to assess the protection and the effectiveness of laparoscopy for managing complicated appendicitis. ${ }^{[21,22]}$

\section{Subjects and Methods}

Present descriptive study was conducted on 50 patients at tertiary care institute of Gujarat for the Period of 1 year. This study is including patients of complicated appendicitis undergoing laparoscopic management. Investigations were done for all the patients and they include $\mathrm{CBC}$, prothrombin time and concentration and renal functions tests and abdominal 
ultrasonography.

Patients with non-complicated appendicitis, prior account of open abdominal or pelvic operations and with medical situation that prohibited them from pneumoperitoneum were expelled from the research.

Camera was bringing in during the $12 \mathrm{~mm}$ periumbilical port. This port was positioned by a Hassan method or direct cut down technique. A $5 \mathrm{~mm}$ port brought in the right lower quadrant under vision. A non-traumatic grasper was set up through this port to recognize the appendix. At this point the small intestine is raise out of the pelvis revealing the inflamed appendix. Careful manipulation was necessary devoid of straight grasping it to avoid bowel injury. ${ }^{[23,24]}$ Peritoneal toilet and aspiration of pus after abdominal exposure. A Maryland grasper was introduced, and a window is created in the mesentery to separate the appendicular artery. Three clips are applied to the isolated vessel. The vessel was separated amid clips leaving two clips on the patient side. Authors then use diathermy to divide the rest of the mesentery. The appendix was afterward ligated and separated at its base with End loops or transected by stapler. Authors evaluate the appendix stump and alienated vessel to ensure hemostasis. Retrieval of the appendix in an Endobag. ${ }^{[25,26]}$

\section{Statistical analysis}

The recorded datas were analyzed using SPSS version 15. For all tests, confidence level and level of significance were set at $95 \%$ and $5 \%$ respectively.

\section{Results}

The study included 50 patients of adult male and female. Mean age of the studied patients was $32.47 \pm 12.10$ years with range between 17 and 66 years. Out of 50 patients, 39 patients were females and 11 patients were males. It was noticed that there was increase of total leucocytic count (leukocytosis) in most of the patients; Mean WBCs was 12.71 \pm 5.37 [Table 1].

All 50 patients underwent diagnostic laparoscopy at first and intraoperative finding were as following. 33 patients had pus free IPF collection and perforated appendicitis (PA), 11 patients had turbid free IPF collection with AA (highly inflamed appendix), 2 case was mucocele of the appendix, 2 cases of appendicular abscess (3.3\%) and 2 cases of gangrenous appendix.

According to conversion to open surgery only five cases $(10 \%)$ were converted to open surgery these cases were appendicular abscess, gangrenous appendix and mucocele of the appendix. 45 cases were successfully preceded to laparoscopic appendectomy.

Post-operative follow up of 50 patients revealed only two cases of postoperative complication in form of wound infection while the other 48 cases hadn't any post-operative complication.

Post-operative hospital stay of all patients were measured and revealed that 7 the cases were stayed one day at the hospital while 39 of the cases were discharged within two days from the admission and 4 of the cases were stared three to four days at the hospital these cases which had prolonged hospital stay were the cases which converted to open surgery. Mean \pm SD (range) of post-operative hospital stay was $2.12 \pm 0.78$ days [Table 2].

\begin{tabular}{ll}
\hline \multicolumn{2}{|c|}{ Table 1: Operative results according to the procedure performed } \\
\hline Parameter & Result \\
\hline Age (years) & $32.47 \pm 12.10$ \\
Male/female & $22 \% / 78 \%$ \\
WBC & $12.71 \pm 5.37$ \\
Conversion rate & $10 \%$ \\
Hospital stay & $2.00 \pm 0.59$ \\
Wound infection & $3.3 \%$ \\
\hline
\end{tabular}

\begin{tabular}{|lll|}
\hline Table 2: Duration of hospital stay among study participants \\
\hline Hospital stay (days) & No. & $\%$ \\
1 & 7 & 14 \\
2 & 39 & 78 \\
$3-4$ & 4 & 8 \\
Mean \pm SD & & $2.12 \pm 0.78$ \\
\hline
\end{tabular}

\section{Discussion}

Complicated appendicitis is linked with a superior hazard of post-operative complications and has been measured a qualified contraindication for laparoscopy. ${ }^{[27-29]}$ nevertheless, this thought has been faced in various researches which compared surgical results of LA for complicated appendicitis. ${ }^{[30-32]}$ Even though a few researchs comparing LA and OA have revealed similarity of the two events as observe morbidity and mortality, ${ }^{[33]}$ most researches accounted important compensation in the laparoscopic group, such as, reduced post-operative pain, quick revival, little hospital reside, ${ }^{[34-36]}$ accessibility of inspection of the whole peritoneal cavity, superior debridement, sufficient irrigation and lavage under straight apparition, improved cosmesis, fewer immunologic cooperation and less chest impediments. ${ }^{[37]}$

A little clinical research on laparoscopic appendectomy for complicated appendicitis have essentially lift a few severe questions. ${ }^{[10-14]}$ Establishment of pneumoperitoneum in a septic surroundings has been concerned; though, the consequence 
of pneumoperitoneum on animal models concerning bacterial translocation has had contentious outcome. ${ }^{[38,39]}$

All 50 patients underwent diagnostic laparoscopy at first and intraoperative finding were as following. 33 patients had pus free IPF collection and perforated appendicitis (PA), 11 patients had turbid free IPF collection with AA (highly inflamed appendix), 2 case was mucocele of the appendix, 2 cases of appendicular abscess (3.3\%) and 2 cases of gangrenous appendix.

According to conversion to open surgery only five cases $(10 \%)$ were converted to open surgery these cases were appendicular abscess, gangrenous appendix and mucocele of the appendix. 45 cases were successfully preceded to laparoscopic appendectomy. Piskun et al, data on 52 patients with perforated appendicitis 10 (19\%) had converted appendectomies. ${ }^{[40]}$ According to So et al, there were 85 patients analyzed with perforated appendicitis in this research undergo laparoscopy 40 patients $(47 \%)$ undergo alteration to the open process after laparoscopy. ${ }^{[41]}$

These findings for laparoscopic appendectomy corroborate the considerably inferior rate of wound healing complications only two cases. According to Lin et al, 15.2\% patients developed wound infections one patient developed intraabdominal bleeding. ${ }^{[42]}$ In Katsuno et al Wound infection was found in $6.4 \%$ of patients in the LA. ${ }^{[43]}$ In Ansari et al, out of 103 patients who were successfully operated laparoscopically, 21 patients developed minor complications like fever in 11 $(10.67 \%)$ patients, $5(4.85 \%)$ patients had postoperative ileus that postponed their begin of oral ingestion and $5(4.85 \%)$ patients had port site infection. ${ }^{[44]}$

These data show a significant reduction in post-operative hospital stay and conversion rate after LA for complicated appendicitis $2.00 \pm 0.59$ days. These results was analogous to numerous earlier studies. ${ }^{[10-12,21-24]}$

\section{Conclusion}

Management of complicated appendicitis laparoscopically is possible, secure and can present a little occurrence of infectious complications, fewer post-operative pain, quick revival and improved cosmesis on the cost of longer operating time than OA. We advocate that LA should be the first option for all patients by complicated appendicitis. It resulted in shorter hospital stay and lower conversion rate.

\section{References}

1. D'Agostino J. Common abdominal emergencies in children. Emerg Med Clin. 2002;20(1):139-153. Available from: https: //doi.org/10.1016/s0733-8627(03)00055-5.

2. Krukowski ZH, Irwin ST, Denholm S, Matheson NA. Preventing wound infection after appendicectomy: A review. Br J Surg.
1988;75(10):1023-1033. Available from: https://dx.doi.org/10. 1002/bjs.1800751023.

3. Frizzele FA, Hanna GB. Pelvic abscess following laparoscopic appendectomy. Surg Endosc. 1996;10(9):947-948. Available from: https://doi.org/10.1007/bf00188493.

4. Ortega AE, Hunter JG, Peters JH, Swanstrom LL, Schirmer B. A prospective, randomized comparison of laparoscopic appendectomy with open appendectomy. Am J Surg. 1995;169(2):208-213. Available from: https://dx.doi.org/10. 1016/s0002-9610(99)80138-x.

5. Bonani F, Reed J, Iii, Hartzell G. Laparoscopic versus conventional appendectomy. J Am Coll Surg. 1994;179:273278.

6. Frazee RC. Laparoscopic Appendectomy for Complicated Appendicitis. Arch Surg. 1996;131(5):509-512. Available from: https://dx.doi.org/10.1001/archsurg.1996. 01430170055010.

7. Tang E, Ortega AE, Anthone GJ, Beart RW. Intraabdominal abscesses following laparoscopic and open appendectomies. Surg Endosc. 1996;10(3):327-328. Available from: https://doi. org/10.1007/bf00187382.

8. Wullstein C, Barkhausen S, Gross E. Results of laparoscopic vs. conventional appendectomy in complicated appendicitis. Dis Colon Rectum. 2001;44(11):1700-1705. Available from: https://dx.doi.org/10.1007/bf02234393.

9. Stöltzing H, Thon K. Perforated Appendicitis: Is Laparoscopic Operation Advisable? Dig Surg. 2000;17(6):610-616. Available from: https://dx.doi.org/10.1159/000051970.

10. Johnson AB, Peetz ME. Laparoscopic appendectomy is an acceptable alternative for the treatment of perforated appendicitis. Surg Endosc . 1998;12(7):940-943. Available from: https://dx.doi.org/10.1007/s004649900752.

11. Ball CG, Kortbeek JB, Kirkpatrick AW, Mitchell P. Laparoscopic appendectomy for complicated appendicitis: an evaluation of postoperative factors. Surg Endosc. 2004;18(6):969973. Available from: https://dx.doi.org/10.1007/s00464-0038262-2.

12. Paya K, Rauhofer U, Rebhandl W, Deluggi S, Horcher E. Perforating appendicitis. An indication for laparoscopy. Surg Endosc. 2000;14(2):182-184. Available from: https://doi.org/ $10.1007 / \mathrm{s} 004649900096$.

13. Semm K. Endoscopic Appendectomy. Endoscopy. 1983;15(02):59-64. Available from: https://dx.doi.org/10. 1055/s-2007-1021466.

14. Cox MR, Mccall J, Toouli J, Padbury R, Wilson T, Wattchow D. A prospective randomized comparison of open versus laparoscopic appendectomy in men. World J Surg. 1996;20(3):263-269. Available from: https://doi.org/10.1007/ s002689900041.

15. Mutter D, Vix M, Bui A, Evrard S, Tassetti V, Breton JF, et al. Laparoscopy not recommended for routine appendectomy in men: Results of a prospective randomized study. Surg. 1996;120(1):71-74. Available from: https://dx.doi.org/10. 1016/s0039-6060(96)80243-1.

16. Williams MD, Collins JN, Wright TF, Fenoglio ME. Laparoscopic Versus Open Appendectomy. South Med J. 1996;89(7):668-674. Available from: https://dx.doi.org/10. 1097/00007611-199607000-00004. 
17. Laine S, Rantala A, Gullichsen R, Ovaska J. Laparoscopic appendectomy - is it worthwhile? Surg Endosc. 1997;11(2):95-97. Available from: https://dx.doi.org/10.1007/ s004649900305.

18. Reiertsen O, Larsen S, Trondsen E, Edwin B, Faerden AE, Rosseland AR. Randomized controlled trial with sequential design of laparoscopic versus conventional appendectomy. $\mathrm{Br}$ J Surg. 1997;84(6):842-849.

19. Garg CP, Vaidya BB, Chengalath MM. Efficacy of laparoscopy in complicated appendicitis. Int J Surg. 2009;7(3):250-252. Available from: https://dx.doi.org/10.1016/j.ijsu.2009.04.007.

20. Fukami Y, Hasegawa H, Sakamoto E, Komatsu S, Hiromatsu T. Value of Laparoscopic Appendectomy in Perforated Appendicitis. World J Surg. 2007;31(1):93-97. Available from: https://dx.doi.org/10.1007/s00268-006-0065-x.

21. Andersson RE, Hugander A, Thulin AJ. Diagnostic accuracy and perforation rate in appendicitis: association with age and sex of the patient and with appendicectomy rate. Eur J Surg. 1992;158(1):37-41.

22. Krukowski ZH, Irwin ST, Denholm S, Matheson NA. Preventing wound infection after appendicectomy: A review. Br J Surg. 1988;75(10):1023-1033. Available from: https://dx.doi.org/10. 1002/bjs. 1800751023 .

23. Guller U, Hervey S, Purves H, Muhlbaier LH, Peterson ED, Eubanks S. Laparoscopic versus open appendectomy: outcomes comparison based on a large administrative database. Ann Surg. 2004;239(1):43-52. Available from: https://doi.org/ 10.1097/01.sla.0000103071.35986.c1.

24. Ortega AE, Hunter JG, Peters JH, Swanstrom LL, Schirmer B. Laparoscopic Appendectomy Study Group. A prospective, randomized comparison of laparoscopic appendectomy with open appendectomy. Am J Surg. 1995;169(212):208221. Available from: https://doi.org/10.1016/s0002-9610(99) 80138-x.

25. Guller U, Hervey S, Purves H, Muhlbaier LH, Peterson ED, Eubanks S. Laparoscopic versus open appendectomy: outcomes comparison based on a large administrative database. Ann Surg. 2004;239(1):43-52. Available from: https://doi.org/ 10.1097/01.sla.0000103071.35986.c1.

26. Ortega AE, Hunter JG, Peters JH, Swanstrom LL, Schirmer B. Laparoscopic Appendectomy Study Group. A prospective, randomized comparison of laparoscopic appendectomy with open appendectomy. Am J Surg. 1995;169(2):208-221. Available from: https://doi.org/10.1016/s0002-9610(99)80138-x.

27. Golub R, Siddiqui F, Pohl D. Laparoscopic Versus Open Appendectomy: A Metaanalysis. J Am Coll Surg. 1998;186(5):545-553. Available from: https://dx.doi.org/10. 1016/s1072-7515(98)00080-5.

28. Sauerland S, Lefering R, Neugebauer EA. Laparoscopic versus open surgery for suspected appendicitis. Cochrane Database Syst Rev. 2004;18(4):1546-1546. Available from: https://doi. org/10.1002/14651858.cd001546.pub2.

29. Pokala N, Sadhasivam S, Kiran RP, Parithivel V. Complicated Appendicitis-Is the Laparoscopic Approach Appropriate? A Comparative Study with the Open Approach: Outcome in a Community Hospital Setting. Am Surg. 2007;73(8):737-742. Available from: https://dx.doi.org/10. 1177/000313480707300801.
30. Guller U, Hervey S, Purves H, Muhlbaier LH, Peterson ED, Eubanks S. Laparoscopic versus open appendectomy: Outcomes comparison based on a large administrative database. Ann Surg. 2004;239(1):43-52. Available from: https://doi.org/ 10.1097/01.sla.0000103071.35986.c1.

31. Mancini GJ, Mancini ML, Nelson HS. Efficacy of Laparoscopic Appendectomy in Appendicitis with Peritonitisa. Am Surg. 2005;71(1):1-5. Available from: https://dx.doi.org/10. 1177/000313480507100101.

32. Yau KK, Siu WT, Tang CN, Yang GP, Li MK. Laparoscopic versus open appendectomy for complicated appendicitis. J Am Coll Surg. 2007;205(1):60-65. Available from: https://doi.org/ 10.1016/j.jamcollsurg.2007.03.017.

33. Shelton T, McKinlay R, Schwartz RW. Acute appendicitis: current diagnosis and treatment. Curr Surg. 2003;60(5):502505. Available from: https://dx.doi.org/10.1016/s01497944(03)00131-4.

34. Lintula H, Kokki H, Vanamo K. Single-blind randomized clinical trial of laparoscopic versus open appendicectomy in children; 2001. Available from: https://doi.org/10.1046/j.13652168.2001.01723.x.

35. Esposito C, Borzi P, Valla JS, Mekki M, Nouri A, Becmeur F, et al. Laparoscopic versus Open Appendectomy in Children: A Retrospective Comparative Study of 2,332 Cases. World J Surg. 2007;31(4):750-755. Available from: https://dx.doi.org/ 10.1007/s00268-006-0699-8.

36. Menezes M, Das L, Alagtal M, Haroun J, Puri P. Laparoscopic appendectomy is recommended for the treatment of complicated appendicitis in children. Pediatr Surg Int. 2008;24(3):303-305. Available from: https://dx.doi.org/10. 1007/s00383-007-2102-8.

37. Cueto J, D'Allemagne B, Vázquez-Frias JA, Gomez S, Delgado F, Trullenque L, et al. Morbidity of laparoscopic surgery for complicated appendicitis: an international study. Surg Endosc. 2006;20(5):717-720. Available from: https://dx.doi.org/10. 1007/s00464-005-0402-4.

38. Ansari IA, Gedam BS, Shah Y, Kale VB, Bansod PY. Laparoscopic appendectomy in acute appendicitis with or without complication. Int J Biomed Res. 2015;6(3):275-275. Available from: https://dx.doi.org/10.7439/ijbar.v6i3.1857.

39. Yagmurlu A, Vernon A, Barnhart DC, Georgeson KE, Harmon CM. Laparoscopic appendectomy for perforated appendicitis: a comparison with open appendectomy. Surg Endosc. 2006;20(7):1051-1054. Available from: https://dx.doi.org/10. 1007/s00464-005-0342-z.

40. Piskun G, Kozik D, Rajpal S, Shaftan G, Fogler R. Comparison of laparoscopic, open, and converted appendectomy for perforated appendicitis. Surg Endosc. 2001;15(7):660-662. Available from: https://dx.doi.org/10.1007/s004640020072.

41. So JBY, Chiong EC, Chiong E, Cheah WK, Lomanto D, Goh P, et al. Laparoscopic appendectomy for perforated appendicitis. World J Surg. 2002;26(12):1485-1488. Available from: https: //dx.doi.org/10.1007/s00268-002-6457-7.

42. Lin JMHF, Wu LM, Tseng KHCSH, Huang IR, Lai. Laparoscopic versus open appendectomy for perforated appendicitis. J Gastrointestinal Surg. 2006;10:906-916.

43. Katsuno G, Fukunaga M, Nagakari K, Yoshikawa S. Laparoscopic one-stage resection of right and left colon complicated 
diverticulitis equivalent to hinchey stage I-II. Surgery Today. 2011;41(5):647-654. Available from: https://dx.doi.org/10. 1007/s00595-010-4349-2.

44. Ansari IA, Gedam BS, Shah Y, Kale VB, Bansod PY. Laparoscopic appendectomy in acute appendicitis with or without complication. Int J Biomed Res. 2015;6(3):275-275. Available from: https://dx.doi.org/10.7439/ijbar.v6i3.1857.

Copyright: (C) the author(s), 2020. It is an open-access article distributed under the terms of the Creative Commons Attribution License (CC BY 4.0), which permits authors to retain ownership of the copyright for their content, and allow anyone to download, reuse, reprint, modify, distribute and/or copy the content as long as the original authors and source are cited.

How to cite this article: Patel P, Jaiswal J. Assessment of the Role of Laparoscopic Management in Patients with Complicated Appendicitis. Acad. J Surg. 2020;3(2):5-9.

DOI: dx.doi.org/10.47008/ajs/2020.3.2.2

Source of Support: Nil, Conflict of Interest: None declared. 